\title{
Class specific immunoglobulin response to individual polypeptides of Chlamydia trachomatis, elementary bodies, and reticulate bodies in patients with chlamydial infection
}

\author{
R CEVENINI, F RUMPIANESI, M DONATI, A MORONI, V SAMBRI, \\ M LA PLACA \\ From the Institute of Microbiology, University of Bologna, Ospedale San Orsola, Bologna, Italy
}

SUMMARY Sera from 10 women with Chlamydia trachomatis culture positive cervicitis and sera from six men with $C$ trachomatis positive non-gonococcal urethritis were studied for the presence of IgG, IgM, and IgA antibodies to polypeptides of $C$ trachomatis elementary bodies and reticulate bodies using immunoblotting techniques. All the sera with $\operatorname{IgG}, \operatorname{IgM}$, or $\operatorname{IgA}$ immunoglobulins specific to $C$ trachomatis recognised the major outer membrane protein (MOMP) of elementary bodies. IgG antibodies also detected several other proteins, whereas IgM immunoglobulins recognised only MOMP and proteins of $60 \mathrm{kD}, 62 \mathrm{kD}$, and $66 \mathrm{kD}$. The IgA reacted with MOMP and the $60 \mathrm{kD}$ and $62 \mathrm{kD}$ proteins in elementary bodies. Class specific antibody response against the proteins of reticulate bodies was similar to that observed for elementary body antigens-with one substantial difference: no reaction was observed in the $60 \mathrm{kD}$ and $62 \mathrm{kD}$ positions. This suggests that $60 \mathrm{kD}$ and $62 \mathrm{kD}$ proteins are deficient in reticulate bodies.

Chlamydiae are pathogenic bacteria that multiply within the cytoplasm of eukaryotic cells, causing these infectious elementary bodies to alternate with noninfectious reticulate bodies. ${ }^{1}$

Genital tract infections caused by Chlamydia trachomatis are a source of major interest in sexually transmitted diseases. Consistent experimental evidence has already been obtained about the aetiological role of $C$ trachomatis in non-gonococcal urethritis in men and cervicitis in women. ${ }^{2}$ The host humoral response to chlamydial antigens in both natural and experimental infections is constant against the major outer membrane protein (MOMP), and often recurring against $60 \mathrm{kD}$ and $62 \mathrm{kD}$ proteins of elementary bodies. ${ }^{34}$ Some sera also react with $45 \mathrm{kD}$ protein and sometimes with other less immunogenic proteins. ${ }^{34}$

This investigation aimed to define the antigenic specificity of class antibody response of patients with $C$ trachomatis cervicitis and urethritis. Sera from patients and controls were tested by SDS-PAGE immunoblotting using purified elementary bodies and reticulate bodies of $C$ trachomatis LGV2 serotype as the antigen.

\section{Material and methods}

Twelve women with $C$ trachomatis culture positive cervicitis and six men with $C$ trachomatis culture positive non-gonococcal urethritis (NGU) were included in this study. The patients were selected on the basis of culture positivity, and the presence in their serum of IgG specific to $C$ trachomatis (titre $\geqslant 1: 16$ ) as determined by immunofluorescence. Sera from 10 $C$ trachomatis negative healthy subjects were also studied as controls.

\section{C trachomatis PURIFICATION}

LGV2 serotype (434/BU strain) was grown in LLCMK2 cells, and elementary bodies were purified 48 hours after infection according to the technique of Caldwell et al, ${ }^{5}$ as described previously. ${ }^{6}$ Reticulate bodies were purified 20 hours after infection using 30 , 


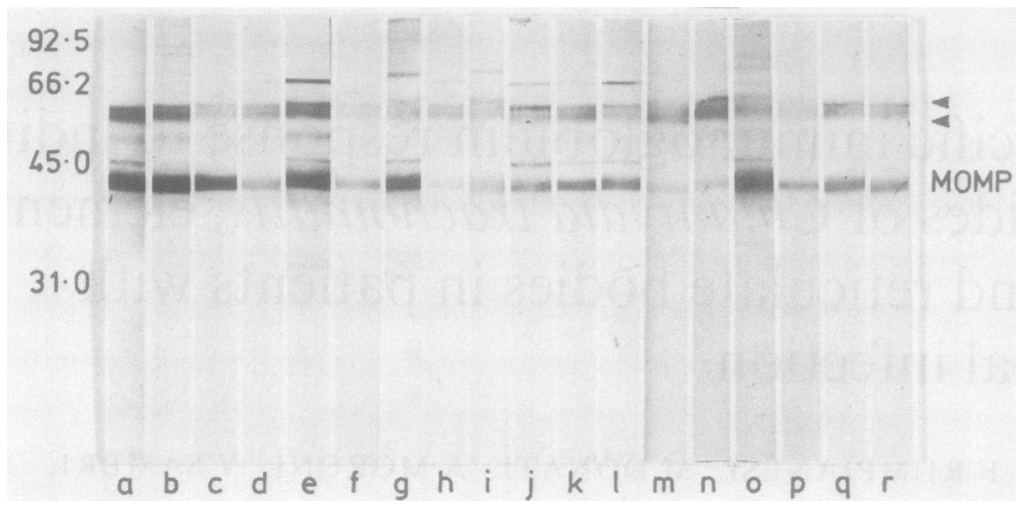

Fig 1 Immunoblot pattern of sera from 12 patients with cervicitis (lanes a-l) and from six patients with urethritis (lanes $m-r$ ). Purified C trachomatis (LGV2 serotype) elementary bodies were applied. Rabbit immunoglobulins to human IgG was used as second antibody. Position and molecular weight of markers are indicated on the left. Arrows indicate $60 \mathrm{kD}$ and $62 \mathrm{kD}$ proteins.

35, and $40 \%$ Renografin (ER, Squibb, Princeton, New Jersey) step gradients. ${ }^{7}$ The SDS-PAGE was performed according to the procedure of Laemmli. ${ }^{8}$

\section{IMMUNOBLOTTING}

The immunoblot procedure of Towbin et $a l^{9}$ and of Bittner et al, ${ }^{10}$ as modified by Batteiger et al, ${ }^{11}$ was used, as previously described. ${ }^{4}$

Electrophoretic transfer was done in $25 \mathrm{mM}$ sodium phosphate $(\mathrm{pH} 7.5)$ at 27 volts $(0.9$ to $1.0 \mathrm{~A})$ for two hours at $20^{\circ} \mathrm{C}$ to HAHY millipore nitrocellulose paper with transblot cell (Bio-Rad Laboratories, Richmond, California). After transfer the nitrocellulose paper was incubated in $50 \mathrm{mM}$ sodium phosphate, $0 \cdot 15 \mathrm{M}$ sodium chloride, $0.02 \%$ sodium nitrate, containing $3 \%$ bovine serum albumin (BSA), for 30 minutes. The nitrocellulose paper was then divided into strips and these were incubated with the patient's serum $1 / 100$ diluted in phosphate buffered saline containing 3\% BSA for 16 hours on a rocker platform. The nitrocellulose paper was washed three times for 10 minutes with phosphate buffered saline followed by incubation with peroxidase labelled rabbit immunoglobulins to human IgG, IgM, or IgA (Dako, Copenhagen, Denmark), respectively, diluted $1 / 1000(\operatorname{IgG})$ and $1 / 400$ (IgM and $\operatorname{IgA})$ in phosphate buffered saline for two hours at room temperature. The nitrocellulose strips were then washed three times for 10 minutes with phosphate buffered saline and transferred to distilled water. The immunoblots were developed with a solution of $\mathbf{4 0} \mathrm{mg}$ benzidine (Fluka AG, Buchs, Switzerland) dissolved in $4 \mathrm{ml}$ acetone, $96 \mathrm{ml}$ phosphate buffered saline, and $0.1 \mathrm{ml}$ hydrogen peroxide from $33 \%$ stock solution. After devel- opment the blots were repeatedly rinsed with distilled water.

\section{CHLAMYDIAL SEROLOGY}

The elementary bodies and the reticulate bodies of $C$ trachomatis LGV2 serotype, purified as described above, were also used as antigen in ace microimmunofluorescence assay (MIF) to assess serum titres specific for IgG, IgM, or IgA immunoglobulins.

\section{Results}

Fig 1 shows the SDS-PAGE pattern of $C$ trachomatis elementary bodies antigens by immunoblotting with sera from 12 women with cervicitis and six men with urethritis, using rabbit immunoglobulins to human IgG as the second antibody. All the sera (with MIF titres for IgG ranging from $1 / 16$ to $1 / 4096$ ) reacted with the major outer membrane protein $(40 \mathrm{kD})$ and with at least two other polypeptides of $60 \mathrm{kD}$ and $62 \mathrm{kD}$. Some sera with MIF titres ranging from $1 / 64$ to $1 / 4096$ also reacted with $66 \mathrm{kD}$ (lanes $\mathrm{e}, \mathrm{h}, \mathrm{j}, \mathrm{k}, \mathrm{l}$ ), with $45 \mathrm{kD}$ protein (lanes a, e, g, j, k, l, o), and with other minor proteins. Fig 2 shows the pattern obtained with the same sera tested with the same procedure against purified $C$ trachomatis reticulate bodies. All the sera reacted with MOMP, some (lanes c, e, $\mathrm{j}, \mathrm{k}, \mathrm{l}, \mathrm{n}, \mathrm{o}$ ) also reacted with the $66 \mathrm{kD}$ protein, but no reaction was observed in the $60 \mathrm{kD}$ and $62 \mathrm{kD}$ positions. When the elementary body immunoblots were developed with the sera of two women exhibiting positive $(\geqslant 1 / 32)$ MIF IgM titres and rabbit immunoglobulins specific to human IgM, only a slight reac- 


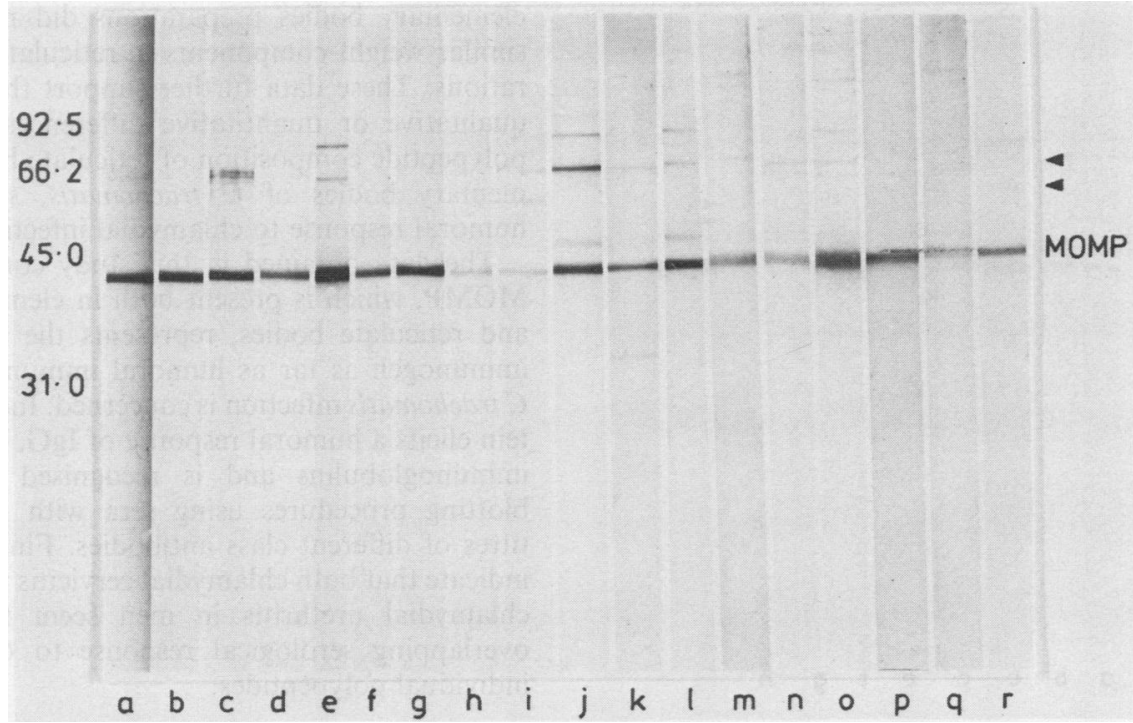

Fig 2 Immunoblot pattern of same sera as described in fig 1, but reticulate bodies were applied for purified C trachomatis. Arrows indicate $60 \mathrm{kD}$ and $62 \mathrm{kD}$ positions.

tion with the MOMP and with the $60 \mathrm{kD}, 62 \mathrm{kD}$, and $66 \mathrm{kD}$ proteins was observed (data not shown). Negative results were obtained with reticulate body preparations (data not shown). The reactivity of $\operatorname{IgA}$ antibodies to $C$ trachomatis elementary bodies and reticulate body individual polypeptides was also studied, using as second antibody, rabbit immuno-

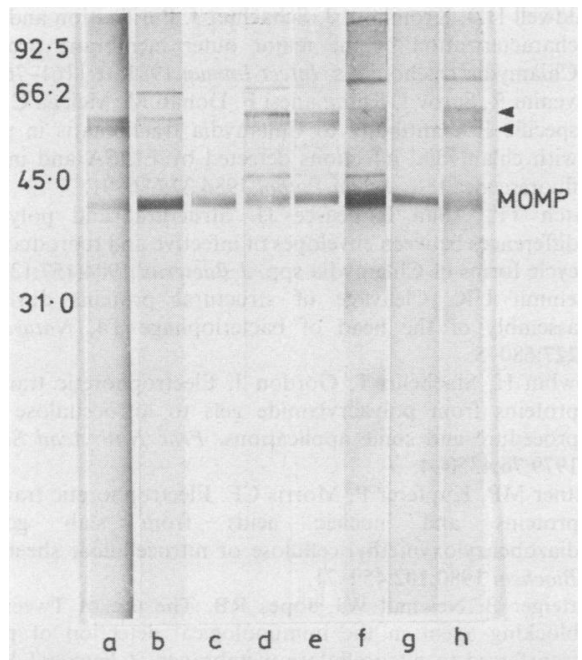

Fig 3 Immunoblot pattern of sera from six patients with cervicitis (lanes $a-f$ ) and two patients with urethritis (lanes $g$ and $h$ ). Purified $C$ trachomatis elementary bodies were applied and rabbit immunoglobulins to human Ig $A$ were used as second antibody. Arrows indicate $60 \mathrm{kD}$ and $62 \mathrm{kD}$ proteins. globulins specific to human IgA. The sera with a MIF IgA titre of $\leqslant 1 / 16$ gave negative results in the blot both with elementary bodies and reticulate bodies. All the IgA positive sera with a MIF IgA titre of $\geqslant 1 / 32$ recognised MOMP, and most of these sera also identified $60 \mathrm{kD}$ and $62 \mathrm{kD}$ proteins in the blot performed with elementary bodies (fig 3 ). When tested with reticulate body preparations (fig 4) some sera (lanes a, b, d, f, and h) detected MOMP and $66 \mathrm{kD}$ protein, and two sera (lanes $\mathrm{c}$ and $\mathrm{g}$ ) detected only MOMP. In the $60 \mathrm{kD}$ and $62 \mathrm{kD}$ positions no reaction was observed. Sera from healthy subjects, which were negative by the various MIF tests, did not react against any $C$ trachomatis protein. ${ }^{4}$

\section{Discussion}

The outer membrane protein of $C$ trachomatis was shown to be one of the primary antigens recognised after animal immunisation with chlamydial elementary bodies. ${ }^{5}$ Other data suggest that the MOMP of $C$ trachomatis elementary bodies is also of primary importance in the IgG humoral response to $C$ trachomatis in patients with chlamydial urethritis. ${ }^{34}$

Our investigation on women with cervicitis and men with urethritis confirmed these findings, showing the relevance of the MOMP as immunogen. In fact, all the sera positive by the MIF test, with titres $\geqslant 1 / 16$ for $\operatorname{IgG}$ or $\geqslant 1 / 32$ for $\operatorname{IgA}$ recognised the MOMP both of elementary bodies and reticulate bodies. Sera with an IgM MIF titre of $\geqslant 1 / 32$ recognised at least the MOMP of elementary bodies. Sera 


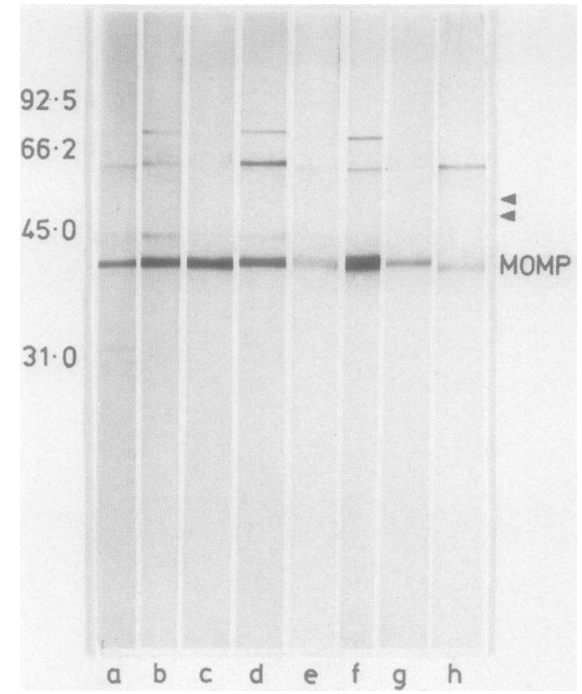

Fig 4 Immunoblot pattern of sera as described in fig 3, but reticulate bodies were applied. Arrows indicate $60 \mathrm{kD}$ and $62 \mathrm{kD}$ positions.

with MIF IgM or IgA titres lower than $1 / 32$ failed in our experimental conditions to detect this antigen in reticulate bodies preparations by immunoblotting. The IgG response against the $60 \mathrm{kD}$ and $62 \mathrm{kD}$ proteins of elementary bodies was quite constant and paralleled that observed against the MOMP. Most of the sera with MIF IgA titres $\geqslant 1 / 32$ also recognised these proteins. Other elementary bodies proteins, in addition to the MOMP, the $60 \mathrm{kD}$, and the $62 \mathrm{kD}$ proteins, were detected by IgG specific immunoglobulins, and in particular the $45 \mathrm{kD}$ and the $66 \mathrm{kD}$ proteins. The IgM immunoglobulins could identify only the $60 \mathrm{kD}, 62 \mathrm{kD}$, and $66 \mathrm{kD}$ proteins besides the MOMP.

The class specific antibody response against reticulate body preparations showed some differences compared with that of the elementary bodies. Most notable was the absence of any reaction in the $60 \mathrm{kD}$ and $62 \mathrm{kD}$ positions when the blot of reticulate bodies were tested with immune sera.

In a previous study Hatch et $a l^{7}$ observed that $C$ trachomatis elementary bodies harvested 48 hours after infection possess three cysteine rich outer membrane proteins of 62,59 , and $12 \mathrm{kD}$, whereas reticulate bodies harvested intracellularly 21 hours after infection were severely deficient in cysteine rich proteins but possessed almost as much MOMP as the elementary bodies. Our results seem to confirm indirectly the deficiency of the $60 \mathrm{kD}$ (this protein may correspond to the $59 \mathrm{kD}$ protein reported by Hatch $e t$ $\left.a l^{7}\right)$ and the $62 \mathrm{kD}$ proteins in reticulate bodies as all the sera reacting with the $60 \mathrm{kD}$ and $62 \mathrm{kD}$ proteins of elementary bodies preparations did not react with similar weight components in reticulate body preparations. These data further support the existence of qualitative or quantitative differences between the polypeptide composition of reticulate bodies and elementary bodies of $C$ trachomatis, shown by the humoral response to chlamydial infection.

The data obtained in this study confirm that the MOMP, which is present both in elementary bodies and reticulate bodies, represents the most relevant immunogen as far as humoral immune response to $C$ trachomatis infection is concerned. Indeed, this protein elicits a humoral response of IgG, IgM, and IgA immunoglobulins and is recognised by immunoblotting procedures using sera with relatively low titres of different class antibodies. Finally, our data indicate that both chlamydial cervicitis in women and chlamydial urethritis in men seem to induce an overlapping serological response to $C$ trachomatis individual polypeptides.

\section{References}

1 Litwin J. The growth cycle of the psittacosis group of organisms. $J$ Infect Dis 1959;109:128-60.

2 Schachter J, Grossman M. Chlamydial infections. Annu Rev Med 1981;32:45-61.

3 Newhall WJ, Batteiger B, Jones RB. Analysis of the human $\vec{\bullet}$ serological response to proteins of Chlamydia trachomatio Infect Immun 1982;38:1181-9.

4 Cevenini R, Rumpianesi F, Sambri V, La Placa M. Antigenin specificity of serological response in Chlamydia trachomatis urethritis detected by immunoblotting. J Clin Pathol 1986, 39:325-7.

5 Caldwell HD, Kromhout J, Schachter J. Purification and partial characterization of the major outer membrane protein of Chlamydia trachomatis. Infect Immun 1981;31:1161-76.

6 Cevenini R, Sarov I, Rumpianesi F, Donatĩ M, Melega C. Serum specific IgA antibody to Chlamydia trachomatis in patients with chlamydial infections detected by ELISA and immunofluorescence test. J Clin Pathol 1984;37:686-91.

7 Hatch TP, Allan I, Pearce JJ. Structural and polypeptide differences between envelopes of infective and reproductive life cycle forms of Chlamydia spp. J Bacteriol 1984;157:13-20.

$8 \mathrm{Laemmli}$ UK. Cleavage of structural proteins during the assembly of the head of bacteriophage T4. Nature 1970; 227:680-5.

9 Towbin H, Staehelin T, Gordon J. Electrophoretic transfer of proteins from polyacrylamide gels to nitrocellulose sheets: procedure and some applications. Proc Natl Acad Sci USA 1979;76:4350-4.

10 Bittner MP, Kupferer P, Morris CF. Electrophoretic transfer of proteins and nucleic acids from slab gels to diazobenzyloxymethyl cellulose or nitrocellulose sheets. Anal o Biochem 1980;102:459-71.

11 Batteiger B, Newhall WJ, Jones RB. The use of Tween-20 as blocking agent in the immunological detection of proteins $\omega$ transferred to nitrocellulose membranes. J Immunol Methods 1982;55:297-307.

Requests for reprints to: $\operatorname{Dr} \mathbf{R}$ Cevenini, Institute of Microbiology, University of Bologna, Ospedale S. Orsola, 9 Via Massarenti, 40138 Bologna, Italy. 